Gut, 1960, 1, 237.

\title{
MASSIVEIRESECTION OF THE SMALL INTESTINE AFTER OCCLUSION OF THE SUPERIOR MESENTERIC ARTERY
}

\section{BY}

\author{
R. J. HARRISON and C. C. BOOTH
}

\section{From St. James's Hospital, Balham, London, and the Postgraduate Medical School of London}

\begin{abstract}
Resection of all the small intestine but the proximal 8 in. of jejunum was performed in an elderly woman. Intestinal function tests revealed an extensive defect of absorption. The patient died nine months after the operation in a state of extreme emaciation. Necropsy revealed hypertrophy of the remnant of small intestine and intense fatty degeneration of the liver.
\end{abstract}

Occlusion of the superior mesenteric artery is one of the commoner causes of extensive gangrene of the small intestine (Haymond, 1935). Resection of large amounts of the small bowel may be necessary but this procedure carries a high post-operative mortality (Bowen and Felger, 1942). Uricchio, Calenda, and Freedman (1954) estimated that approximately 1,350 cases of mesenteric artery occlusion had been reported in the literature but they were able to find only 158 cases in which recovery followed resection. Thirty-two patients were studied by Wilson and Block (1956); 12 were subjected to resection and only two of these survived for as long as three months. In individual cases, however, extensive resection after arterial obstruction may be compatible with life and survival is possible with only 14 to $18 \mathrm{in}$. of residual small intestine (Meyer, 1946 and 1954; Cogswell, 1948; Althausen, Uyeyama, and Simpson, 1949; Schwartze, Medwid, Roberts, Sleisenger, and Randall, 1956; Kogan, Schapira, Janowitz, and Aldersberg, 1957).

We have recently had the opportunity of observing a woman who had an extensive resection of the small intestine after thrombosis of the superior mesenteric artery. Only 8 in. of the jejunum remained, yet she survived for nine months after the operation.

\section{Case Report}

A.S., a widow aged 80 , was admitted to St. James's Hospital, Balham, on November 20, 1958, complaining of progressive shortness of breath on exertion and epigastric discomfort after meals.

Clinical examination showed a healthy-looking elderly woman (weight 9 st. 4 lb.). The mucous membranes were pale. Jugular venous pressure was elevated to $2 \mathrm{~cm}$. above the sternal angle, slight sacral oedema was noted, and fine crepitations were heard over both lung bases. The pulse was regular and blood pressure $225 / 115 \mathrm{~mm}$. Hg. The apex beat was palpable in the fifth left intercostal space $\frac{1}{2}$ in. outside the midclavicular line. A soft systolic murmur was present in the aortic area.

Investigations revealed $\mathrm{Hb} 6.1$ g. $\%(48 \%)$; R.B.C.s $3.1 \mathrm{~m}$. per c.mm.; P.C.V. $25 \%$; and W.B.C. 7,950 per c.mm. Stained blood films showed evidence of iron deficiency. Occult blood was present in the stools. Serum proteins were $6.5 \mathrm{~g}$. \% (albumin $4.4 \mathrm{~g}$., globulin $2.1 \mathrm{~g}$.) and blood urea $32 \mathrm{mg}$. \%. A radiograph of the chest showed slight left ventricular enlargement and a barium meal revealed a small sliding hiatus hernia. In the E.C.G. there was inversion of the $T$ waves over the anterior chest leads (V3 to 6), suggesting left ventricular ischaemia.

Treatment and Progress.-A diagnosis of irondeficiency anaemia secondary to chronic blood loss from a hiatus hernia was made. She was treated with oral iron (ferrous sulphate, grains 3 , three times daily). She also received "digoxin" ( $0.25 \mathrm{mg}$. three times daily) and chlorothiazide (1 g. once weekly). On November 26 (one week after admission) she had an acute attack of pain in the left lower chest, radiating to the left shoulder and exaggerated by inspiration. She was not shocked (B.P. 215/105) but an E.C.G. now showed further inversion of the $T$ waves, suggesting an episode of myocardial ischaemia. The pain was relieved by pethidine (100 mg. subcutaneously) and did not recur. By December 13, the $\mathrm{Hb}$ had risen to $68 \%$ and she felt well. On December 20 she was discharged home, but that night she had an attack of abdominal pain and vomiting. She recovered from this but on December 25 before breakfast she had a sudden attack of severe abdominal pain followed by vomiting, and was readmitted to St. James's Hospital, Balham, at once.

Clinical examination revealed generalized abdominal tenderness and guarding, and the bowel sounds were absent. Her pulse was regular; blood pressure was 


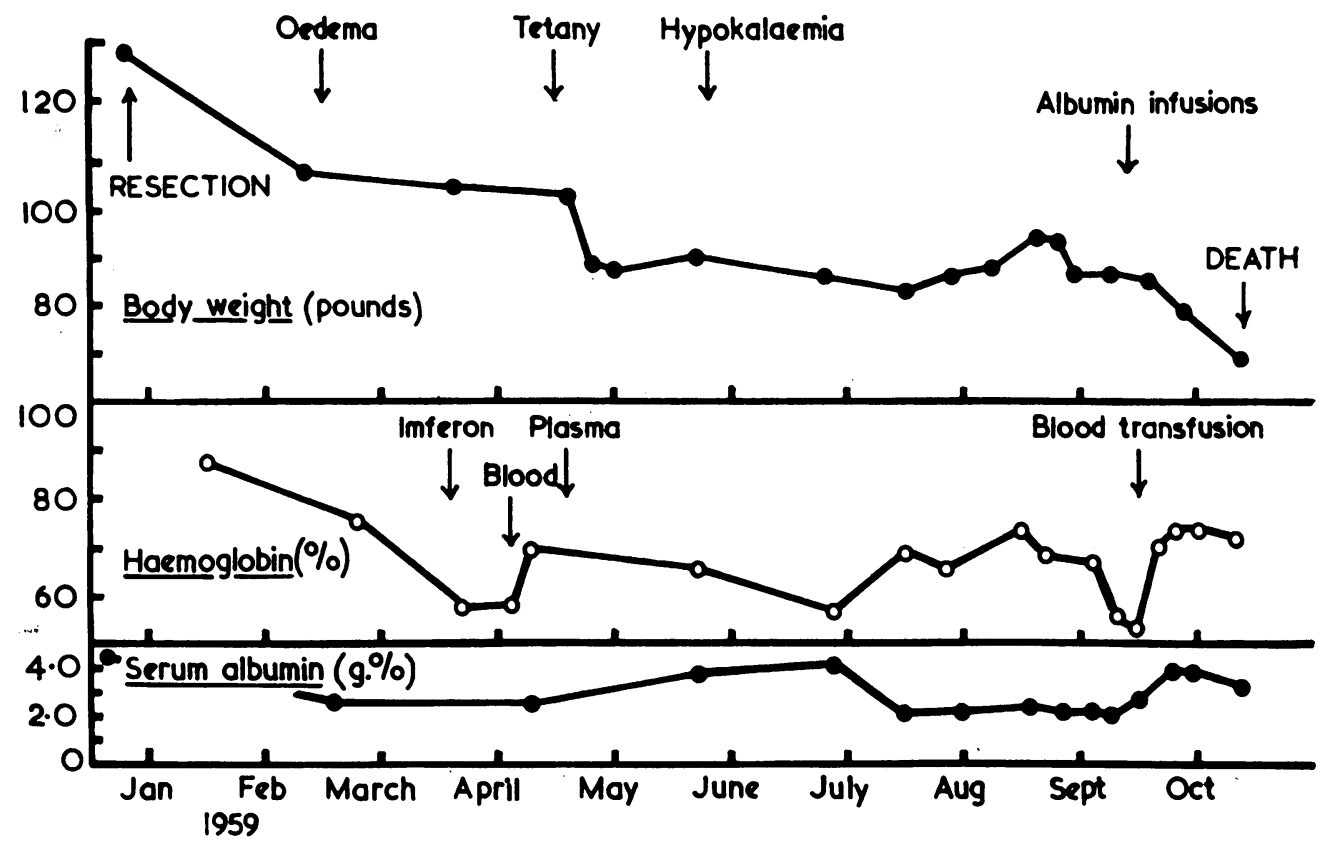

FIG. 1.-Body weight, haemoglobin, and serum albumin levels from the time of the resection until death.

$130 / 90 \mathrm{~mm}$. $\mathrm{Hg}$ and the jugular venous pressure not raised.

Treatment and Progress after Readmission.-A diagnosis of peritonitis was made and immediate laparotomy was performed (Mr. I. Penn). There was foulsmelling purulent fluid in the peritoneal cavity and the intestine was found to be gangrenous from a point just beyond the duodeno-jejunal flexure to the mid-ascending colon. The superior mesenteric artery was not pulsating and was occluded by thrombus. As a life-saving measure an extensive resection was carried out, an end-to-end anastomosis being performed between the upper jejunum and the ascending colon. It was estimated that approximately 8 in. of jejunum remained. Post-operatively the patient was treated with parenteral fluids and antibiotics. She made a good recovery and by December 31 was able to take a light fluid diet, although she had profuse diarrhoea, passing between two and 12 loose, watery motions daily. She was treated with a high-protein, lowfat diet (approximately $30 \mathrm{~g}$. fat daily) and she also received parenteral injections of vitamins $A, B_{12}, D_{1}$ and $\mathbf{K}$. Her subsequent progress is illustrated in Fig. 1. Seven weeks after the operation her weight had decreased by $22 \mathrm{lb}$. and the serum albumin had fallen to 2.7 g. $\%$; ankle oedema developed. Her protein intake was increased to approximately $100 \mathrm{~g}$. daily. Twelve weeks post-operatively she had persistent oedema; haemoglobin had fallen to $56 \%$, although there was no occult blood in the stools. Chlorothiazide $(1 \mathrm{~g}$. twice weekly) was started and she was given "imferon" (40 ml. in divided doses during the next two weeks). The haemoglobin did not rise and 2 pints of blood were then given. By the middle of April, 1959 (16 weeks postoperatively), she had developed tetany (serum Ca $4.3 \mathrm{mEq}$./litre) which was relieved by injections of calcium gluconate. The oedema and hypoproteinaemia persisted and 5 pints of plasma were given by intravenous infusion. The serum albumin level increased following this treatment and there was a diuresis with further loss of weight (Fig. 1). At this time she was feeling well and she was able to take a high-protein, low-fat diet that included beef steak, sole, and chicken. She now passed between one and three bulky, fluid stools daily. In May, 1959, following a bout of severe diarrhoea, the serum potassium level fell to $2.6 \mathrm{mEq}$./litre and she was given oral potassium chloride (1 g. three times daily). She was also treated with testosterone propionate $(5 \mathrm{mg}$. daily) and liver extract (1 $\mathrm{ml}$. of "hepostab" weekly). On July 16, 1959, she was transferred to Hammersmith Hospital.

Clinical examination showed her to be a bright, alert old lady with signs of marked wasting and weight loss. Blood pressure was $140 / 90 \mathrm{~mm}$. Hg. There was moderate oedema of the legs and sacrum, but the jugular venous pressure was not elevated.

INVESTIGATIONS OF INTESTINAL FUNCTION.-The following investigations were performed:-

Intestinal Anatomy.-A barium follow-through showed slight dilatation of the small amount of remaining small intestine (Fig. 2). Some of the barium had passed into the colon within five minutes. 


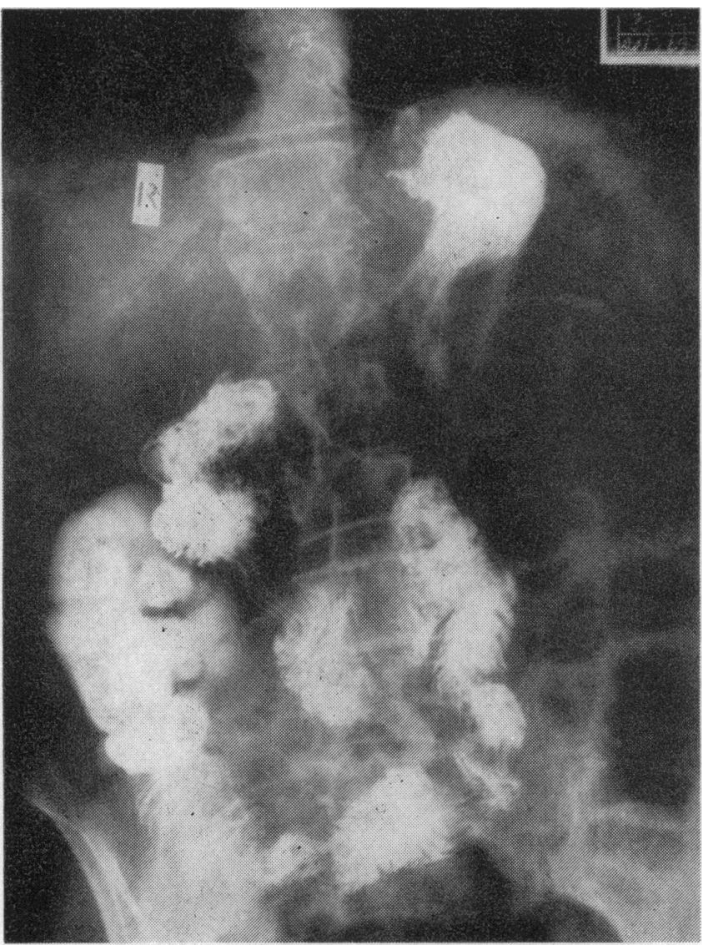

FIG. 2.-Barium follow-through examination (10-minute film) showing stomach, remaining small intestine, and ascending colon.

Intestinal Function Tests.-These are shown in Fig. 3. Glucose tolerance tests were flat and slow to rise. Folic acid absorption was subnormal (Chanarin, Anderson, and Mollin, 1958). While on a $30 \mathrm{~g}$. fat diet, her faecal fat excretion was $15 \mathrm{~g}$. per day over a three-day balance period. Her absorption of ${ }^{58} \mathrm{Co}$-labelled $\mathrm{B}_{12}$ was measured using the method described by Glass (1954) and showed no absorption of this vitamin.

Haematological Findings.-Haemoplasm was 9.7 g. $\%$ $(59 \%)$, R.B.C.s 3.3 m. per c.mm., P.C.V. $28 \%$. Sternal marrow showed normoblastic erythropoiesis with abundant iron stores. Serum $B_{12}$ concentration was $310 \mu \mu g$. per ml. (normal 140 to $900 \mu \mu \mathrm{g}$. per ml., Mollin and Ross, 1957). No occult blood was found in specimens of faeces tested repeatedly.

Proteins and Electrolytes.-Serum proteins were $4.4 \mathrm{~g}$. per $100 \mathrm{ml}$. (albumin $2.0 \mathrm{~g}$., globulin $2.4 \mathrm{~g}$.). Serum $\mathrm{Na}$ was 145, K 3.6, Cl 104, and $\mathrm{HCO}_{3} 27 \mathrm{mEq}$./ litre. Serum $\mathrm{Ca}$ was 4.0 and phosphate $1.2 \mathrm{mEq}$./litre. Alkaline phosphatase was 10 King-Armstrong units.

Treatment and Progress.-At this time the patient was passing between one and three fluid stools daily, A diet containing $40 \mathrm{~g}$. of fat produced severe diarrhoea. as did a fluid diet consisting of glucose drinks and fruit

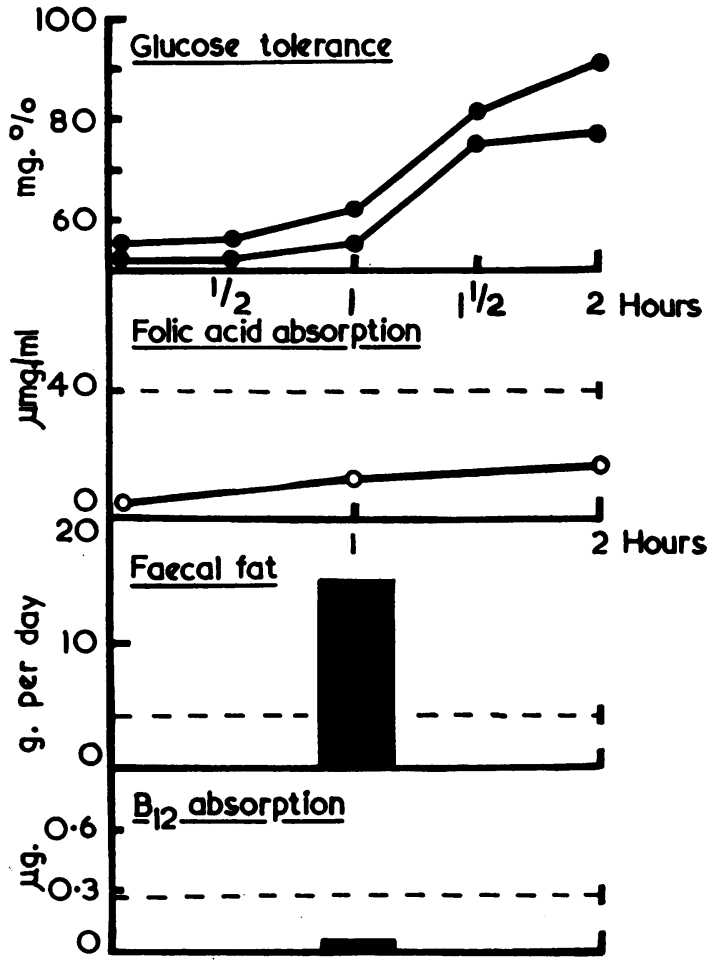

Fig. 3.-Intestinal function tests. After an oral dose the serum level of folic acid is greater than $40 \mu \mathrm{g}$. per ml. in control subjects (Chanarin et al., 1958). Normal $B_{12}$ absorption from an oral dose of $1 \mu \mathrm{g}$. is greater than 0.28 $\mu g$. (Mollin et al., 1957).

juice; diarrhoea was best controlled by a solid highprotein diet containing less than $30 \mathrm{~g}$. of fat daily. Despite this treatment, serum albumin remained low and anaemia persisted. Her weight increased gradually as she accumulated oedema (Fig. 1) but fell when "mersalyl" ( $2 \mathrm{ml}$. once weekly) was given. By the middle of September, 1959, Hb had fallen to $54 \%$ but sternal marrow examination again showed normoblastic erythropoiesis and no occult blood was present in the stools. She was given 2 pints of blood and intravenous infusions of salt-free human albumin (total $450 \mathrm{~g}$.) and haemoglobin and serum proteins increased (Fig. 1). Her general condition, however, deteriorated steadily and by September 29, 1959, she had developed signs of a right basal pneumonia. Serum magnesium was measured at this time and was found to be $1.5 \mathrm{mEq}$./litre (normal 1.5 to $1.8 \mathrm{mEq}$./litre). She died in a condition of extreme emaciation on October 8.

NeCropsy Findings (Professor C. V. Harrison).-The necropsy confirmed the extremely emaciated appearance of the patient. Internally, the remaining jejunum measured $25 \mathrm{~cm}$.; it was soundly anastomosed to the mid-ascending colon. After fixation the jejunum measured $19 \mathrm{~cm}$. in length and had a circumference of between 11 and $13 \mathrm{~cm}$. (Fig. 4). A similar length of 


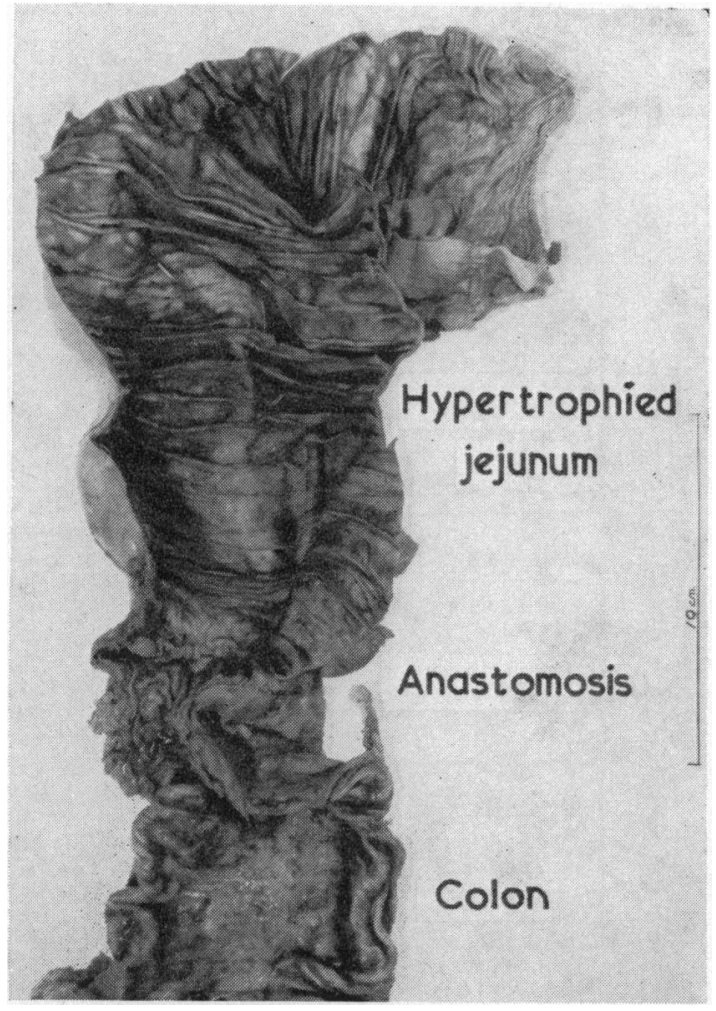

FIG. 4.-Necropsy specimen of jejunum showing marked enlargement in transverse diameter due to hypertrophy of mucosal and muscle layers.

jejunum from a woman aged 65 had a circumference of 6.5 to $7.5 \mathrm{~cm}$. The weights of the remaining jejunum and of the control specimen were $90 \mathrm{~g}$. and $72 \mathrm{~g}$. respectively. Microscopically, the muscle wall of the jejunum appeared hypertrophied and the mucosa showed many mitoses. The colon appeared normal.

The liver weighed 1,015 g. and showed marked fatty change, mainly in the periportal areas (Fig. 5). The pancreas was normal.

The pericardium was totally adherent and showed small plaques of calcification and of old caseation. Microscopically these were fibrous and acellular but there were also some recent tubercles. The heart was of normal size. The aorta showed mild atheroma.

The right pleura was loosely adherent and the visceral layer showed a series of raised plaques which proved to be tubercles. The right lung was oedematous and there was a purulent bronchitis. Microscopically there was early pneumonia and in some alveoli the reaction was tuberculous. A single acid-fast bacillus was seen in one of these lesions. The left lung showed a basal infarct.

\section{Discussion}

The cause of the mesenteric vascular occlusion in this patient was uncertain. Since there was no

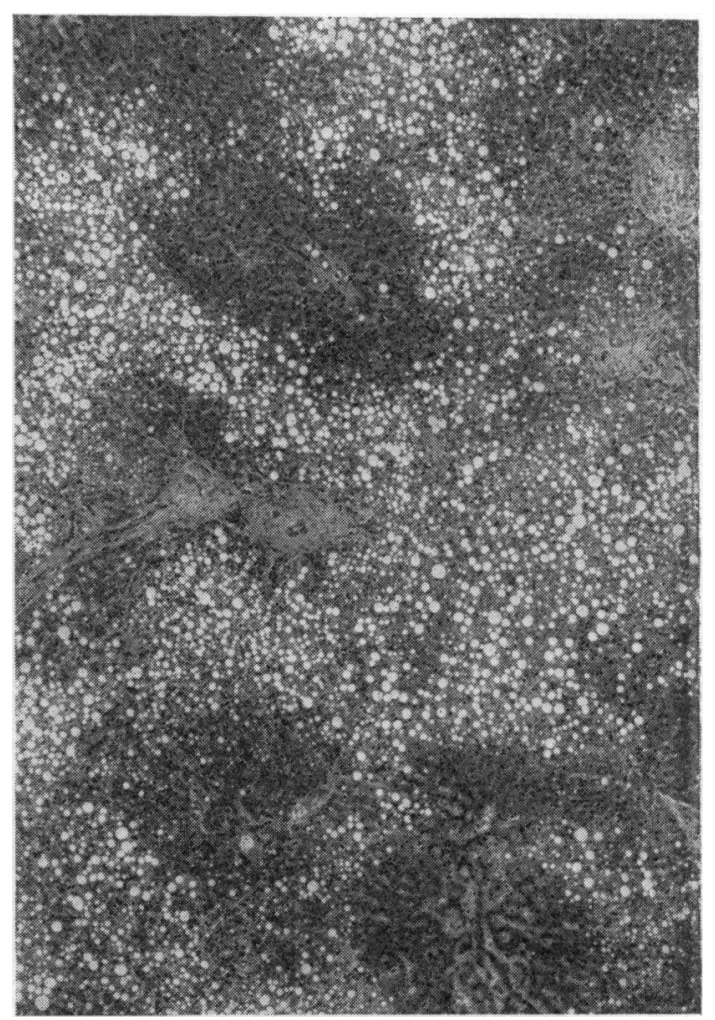

FIG. 5.-Photomicrograph of liver $(\times 36)$ showing intense fatty degeneration (haemotoxylin and eosin).

obvious source of embolism, it seems likely that it was due to thrombosis of the superior mesenteric artery. Thrombosis may sometimes occur during the course of treatment of chronic anaemia and this may have happened in our patient.

Estimations of the amount of small intestine remaining after massive resection are notoriously inaccurate (Flint, 1912). In this patient, however, the surgeon's observation that 8 in. of jejunum remained was confirmed by the radiological studies (Fig. 2) and at necropsy (Fig. 4). It is therefore not surprising that barium passed through the remaining small intestine within five minutes or that there was an extensive defect in intestinal absorption (Fig. 3). The glucose tolerance curves were flat and rose slowly, suggesting that glucose may have been absorbed from the colon rather than the small intestine in this patient (Jackson, 1958). Folic acid absorption was subnormal, indicating that this substance requires more than 8 in. of the jejunum for its absorption. Although there was marked steatorrhoea, it appeared that approximately $50 \%$ of the dietary fat $(30 \mathrm{~g}$.) was absorbed from the 
small amount of residual intestine. Absorption of $B_{12}$ has been found to be subnormal in patients subjected to massive intestinal resection (McIntyre, Sachs, Krevans, and Conley, 1956; Mollin, Booth, and Baker, 1957). This is in keeping with the observation that $\mathbf{B}_{12}$ is absorbed in the ileum in man (Booth and Mollin, 1959). It was not possible to obtain satisfactory data for nitrogen balance studies in this patient. However, the progressive loss of weight, hypoalbuminaemia, and oedema indicate that she was unable to absorb sufficient protein to maintain nutrition. It is in fact surprising that she survived for as long as nine months.

The cause of the persistent anaemia is uncertain. There was no evidence of any specific vitamin deficiency. She had been given injections of vitamin $B_{12}$ and the serum $B_{12}$ concentration was normal. Sternal marrow on two occasions revealed no evidence of megaloblastic change to suggest a folic acid deficiency and iron was abundant in the marrow fragments. Whilst it is tempting to postulate that protein deficiency may have contributed to the anaemia, it is more likely that blood volume changes associated with hypoalbuminaemia and oedema were a major factor.

Magnesium deficiency has recently been recorded in a patient who had gross steatorrhoea associated with a massive intestinal resection (Fletcher, Henly, Sammons, and Squire, 1960). In this patient the large amounts of fat excreted daily may have depleted the body by binding magnesium as soaps. It is interesting that in our patient, in whom steatorrhoea had been controlled by giving an extremely low-fat diet, the serum magnesium before death was normal.

The response of the human small intestine to resection has been studied in a large number of individual cases (Jackson, 1958) yet there is no unanimity of opinion as to whether the remaining intestine hypertrophies. In some instances, it has been stated that "compensatory" hypertrophy follows massive resection (Flint, 1912; Jackson, 1958) but in other cases no such hypertrophy has been observed (Shonyo and Jackson, 1950; Shelton and Blaine, 1954). Furthermore, in experimental animals the site of the resection may play a part in determining whether hypertrophy occurs (Booth, Evans, Menzies, and Street, 1959). In our patient, however, the necropsy specimen showed undoubted evidence of hypertrophy, for the calibre of the residual small intestine was considerably greater than that of a control and was in fact greater than that of the colon (Fig. 4). There was histological evidence of hypertrophy of the muscle layer and the mucosal cells showed many mitoses.

The extensive fatty change found in the liver (Fig. 5) is characteristic of patients who die after prolonged malnutrition (Dible, 1951). Similar fatty change after resection has been reported by Linder, Jackson, and Linder (1953). Pancreatic atrophy may sometimes be associated with intestinal resection in man (Linder et al., 1953), but the pancreas was normal, possibly because the malnutrition had not been of sufficiently long duration. The tuberculous pericarditis and pleurisy found at necropsy were unexpected findings and may represent a longstanding tuberculous infection which had been reactivated during the period of malnutrition that preceded her death. In retrospect, it may have been significant that our patient's mother died of tuberculosis when her daughter was 5 years old.

We wish to thank Mr. Norman Tanner, F.R.C.S., for permission to give details of this patient while she was under his care; Dr. D. L. Mollin and Dr. I. Chanarin for the $B_{12}$ and folic acid absorption tests; Dr. I. McIntyre for the estimation of serum magnesium; and Professor C. V. Harrison for the necropsy report.

\section{REFERENCES}

Althausen, T. L., Uyeyama, K., and Simpson, R. G. (1949). Gastroenterology, 12, 795.

Booth, C. C., and Mollin, D. L. (1959). Lancet, 1, 18.

, Evans, K. T., Menzies, T., and Street, D. F. (1959). Brit. J. Surg., 46, 403.

Bowen, A., and Felger, L. (1942). Mississippi V. med. J., 64, 24.

Chanarin, I., Anderson, B. B., and Mollin, D. L. (1958). Brit. J. Haemat., 4, 156.

Cogswell, H. D. (1948). Ann. Surg., 127, 377.

Dible, J. H. (1951). Brit. med. J., 1, 833 .

Fletcher, R. F., Henly, A. A., Sammons, H. G., and Squire, J. R. (1960). Lancet, 1, 522 .'

Flint, J. M. (1912). Bull. Johns Hopk. Hosp., 23, 127.

Glass, G. B. J. (1954). Clin. Res. Proc., 2, 32.

Haymond, H. E. (1935). Surg. Gynec. Obstet., 61, 693.

Jackson, W. P. U. (1958). "Massive resection of the small intestine." In Modern Trends in Gastroenterology, pp. 243-261, 2nd series, ed. F. Avery Jones. Butterworth, London.

Kogan, E., Schapira, A., Janowitz, H. D., and Adlersberg, D. (1957). J. Mt Sinai Hosp., 24, 408.

Linder, A. M., Jackson, W. P. U., and Linder, G. C. (1953). S. Afr. J. clin. Sci., 4, 1 .

McIntyre, P., Sachs, M. V., Krevans, J. R., and Conley, C. L. (1956). A.M.A. Arch. intern. Med., 98, 541 .

Meyer, H. W. (1946). Arch. Surg. (Chicago), 53, 298.

(1954). Ann. Surg., 140, 447.

Mollin, D. L., Booth, C. C., and Baker, S. J. (1957). Brit. J. Haemat., 3, 412.

-, and Ross, G. I. M. (1957), "The pathophysiology of vitamin $B_{12}$ deficiency in the megaloblastic anaemias." In Vitamin $B_{12}$ and Intrinsic Factor. 1. Europäischen Symposion, Hamburg, 1956, ed. H. C. Heinrich, pp. 413-430. Enke, Stuttgart.

Schwart M. K. Medwid, A., Roberts, K. A., Sleisenger, M., and Randall, H. J. (1956). Surg. Forum, 6, 385 (41st Clinical Congress of the American College of Surgeons, 1955).

Shelton, E. L., and Blaine, M. H. (1954). Tex. St. J. Med., $50,96$. Shonyo, E. S., and Jackson, J. A. (1950). Arch. Surg. (Chicago), 61, 123.'

Uricchio, J. F., Calenda, D. G., and Freedman, D. (1954). Ann. Surg., 139, 206

Wilson, G. S. M., and Block, J. (1956). A.M.A. Arch. Surg., 73, 330. 